\title{
CDC7 wt Allele
}

National Cancer Institute

\section{Source}

National Cancer Institute. CDC7 wt Allele. NCI Thesaurus. Code C52291.

Human CDC7 wild-type allele is located in the vicinity of 1 p22 and is approximately $25 \mathrm{~kb}$ in length. This allele, which encodes cell division cycle 7-related protein kinase, is involved in the regulation of both chromosome replication and the G1/S phase transition for the cell cycle. 